\title{
Dictynna
}

Dictynna

Revue de poétique latine

$14 \mid 2017$

Varia

\section{Segmentation and interpretation in Odes 2}

\section{S.J. Heyworth}

\section{(2) OpenEdition}

Journals

Electronic version

URL: http://journals.openedition.org/dictynna/1458

DOI: $10.4000 /$ dictynna. 1458

ISSN: 1765-3142

\section{Electronic reference}

S.J. Heyworth, « Segmentation and interpretation in Odes 2 », Dictynna [Online], 14 | 2017, Online since 01 December 2017, connection on 10 September 2020. URL : http://journals.openedition.org/ dictynna/1458 ; DOI : https://doi.org/10.4000/dictynna.1458

This text was automatically generated on 10 September 2020 .

\section{(c) (i) (9)}

Les contenus des la revue Dictynna sont mis à disposition selon les termes de la Licence Creative Commons Attribution - Pas d'Utilisation Commerciale - Pas de Modification 4.0 International. 


\section{Segmentation and interpretation in Odes 2}

\section{S.J. Heyworth}

1 The sense of each Horatian Ode as a self contained unit has played a major part in interpretation since the $18^{\text {th }}$ century. Recent work by Schmidt ${ }^{1}$ and Wilson ${ }^{2}$ has celebrated the move towards such integrated reading and away from the piecemeal observation on points of difficulty that characterized earlier commentaries, including of course that most famous Horatian edition, by Richard Bentley. Chapter 19 of Schmidt's book is concerned, as its title tells us, with the 'Hermeneutische Prinzipien' for reading the Odes in the $18^{\text {th }}$ century, and pages $432-6$ bring out the importance of various comments in the edition of Jani on the need for careful reading to discover the unity of the individual Ode. Particularly interesting is Jani's stressing of the difference between Horatian lyric and longer, more unified poetic forms, which makes it essential for the interpreter to submerge himself in the argument of each individual piece:

Aliud difficultatis genus in eo inest, quod, cum in aliorum poëtarum longioribus carminibus uno tenore rem suam peragere interpres possit, in Horatio singulum carmen aliam speciem, alium spiritum, aliam elocutionem habet; ut interpretem continuo oporteat transformare quasi animum suum, aliosque prorsus sensus concipere, si recte perfungi officio, et in cuiusque carminis argumentum se penitus, ut par est, immergere velit. ${ }^{3}$

Another kind of difficulty here is that, while in the longer poems of other poets the interpreter can pursue his reading along a single track, in Horace an individual poem has a variety of appearance, spirit, expression, with the result that the interpreter has constantly to transform his attitude, and to conceive quite different senses, if he wishes to do his job properly and to submerge himself deeply, as is right, in the argument of each poem.

Wilson has subsequently pointed to similar, if less theorized, attention to the Ode as a unit in the English commentaries of Davidson ${ }^{4}$ and especially Watson. ${ }^{5}$ Jani begins the commentary on each poem with its 'Argumentum'; Watson, as he announces in his preface (p. V), ends with the 'Key'.

The Poetical Beauties, Design, and Manner how it is conducted, I thought best to

throw into a continued Discourse at the End of each Ode. This I call the Key, and 
hope it will be of great Benefit to my young Reader, in giving him a Relish of Horace's Excellencies, and forming his Taste and Judgement.

For an instance of Jani's Argumentum we might consider that on 2.13:

Calendis Martii deambulantem vel recubantem in agro praedii sui Sabini poëtam, arbor corruens prope oppresserat; cuius rei mentionem saepius facit, ut inf. 17.27, III.4.27. Tam levis casus tamque vulgaris occasio excellentissimum et splendidissimum carmen protulit; in quo maxime exsplendescit ars illa Horatii, levissimae etiam rei carmine nobilitandae, quam e.g. in carminibus I.17 et 22 admiramur. Est illud ex eo genere, cum ingenium poëtae a sensu quodam, tamquam puncto, quasi egreditur, sed post ad alium sensum, qui ex isto naturali consecutione fluit, transit, eique usque ad finem immoratur. ... Itaque cum hac etiam in ode, naturali prorsus nexu sensus alii ex aliis fluant; cum eos ita expresserit poëta, uti in animo ipsius sibi invicem successissent: mireris sane, esse potuisse, qui digressiones, aberrationes, perturbationes viderent, qui nexum nullum, nullam unitatem, ut vocant, inesse clamarent.' ${ }^{6}$

While walking on land in his Sabine estate on the Kalends of March the poet was nearly crushed by a falling tree. He often makes mention of this fact (e.g. at 2.17.27, 3.4.27). So insignificant an event and so humble an occurrence has produced a very fine and splendid poem; in this there is revealed most splendidly Horace's particular skill of ennobling even the slightest event in song, such as we admire in 1.17 and 1.22. It is an instance of the kind where the poet's genius sets out from a certain perception, a certain point, so to speak, but then goes on to another perception, which flows from the first in a natural sequence, and lingers there up to the end ... <fuller exposition follows $>$... So when in this Ode too different perceptions flow from each other through quite natural connexions, and the poet has expressed them just as they succeeded each other in turn in his mind, you may be amazed that there could be critics who find digressions, divagations, confusions here, and who announce (as they do) that it lacks any connexion, any unity.

3 For Watson's 'Keys' I offer as examples those on 2.14 and 15, the other two Odes with which I shall be concerned in this paper:

[2.14] The Length of human Life is uncertain to us, as its Period is certain and fixed by divine Providence. It rolls on through its several Stages without delay, and hastens to Death, the final Period and irrevocable Fate of Mankind; from which neither rich nor poor are exempt. Death robs us of all our earthly Pleasures, and fixes us in a State, where we can repeat none of them. Our Heirs succeed us upon the Scene, and frequently indulge those Satisfactions that we have foolishly denied ourselves, or squander away in Luxury what we have hoarded up with insatiable Avarice.

The first three sentences may be reasonable generalizations on the basis of the text, but the one about heirs builds most of its tone ('foolishly', 'insatiable avarice') on one dubious word within the final paragraph: dignior, which editors might be wise to emend or obelize (as we shall see). This immediately brings up one methodological issue: interpretation is founded on text, and classical Latin texts are not reliably transmitted, a point of which we should try to be aware, even while doing the best we can with the texts we have. The consequences of dignior continue to be apparent through the rest of the Key, which ends 'The Consequence therefore is, that he should live in a more open and liberal manner, and indulge himself while he has it in his power.' Advice to Postumus to be more generous with his wine thus becomes for Watson the overriding issue of a poem on the inevitability of death: there are dangers in trying to find a key to each poem as a unity. 
The next poem, 2.15, is an unusual Ode, which describes the threat decadence and building poses to agricultural land, and contrasts this with earlier Roman attitudes to wealth and display. What I want to stress from Watson's Key is the word 'Satire':

[2.15] Mankind are, for the most part prone to run into extremes. Parsimony degenerates into Avarice, and Magnificence easily runs into Luxury. When the Roman Commonwealth was in its Progress towards its Prime, it was frugal, parsimonious, and sober in its Manners: the People sought to raise and recommend themselves by all the Instances of publick Virtue and private Temperance; but in proportion as they increased in Wealth and Power, they refined upon the Arts of Luxury and Magnificence; to support which Rapaciousness and Corruption became necessary. Instead of labouring and exercising themselves in the open Air, they now sought the Shade; instead of a few Acres of Ground, they wanted now to extend their Possessions without bounds or measure; and, instead of Piety to the Gods, for which their Ancestors were renowned, they turned their Zeal into the Channel of private Interest, and loved to dwell more magnificently than their Gods. So that Horace, in this Ode, gives as severe a Satire against the Manners of the Age in which he lived, as he draws a beautiful picture out of the Chastity and Simplicity of ancient Manners.

The absence of both addressee and sense of occasion certainly takes us away from Horace's lyric norms.

Next let us consider comments by Dacier and Villeneuve on 2.13: this is the Ode that begins with abuse of the planter of the tree that fell and nearly killed Horace, before moving on to reflections on death and five stanzas on what he nearly saw in the Underworld, namely Sappho and (especially) Alcaeus performing to a rapt audience of souls and demons.

La chute de l'arbre qui avoit pensé écraser Horace n'est pas le veritable sujet de cette Ode, Horace employe seulement cette circonstance pour parler de Sapho et d'Alcée.'

Le ton de la dernière partie (v. 13-40) est évidemment sérieux; ce serait donc prêter au poète une faute de gout d'imaginer qu'il ait voulu mettre dans les imprécations du début une violence comique: il s'est proposé d'un bout à l'autre de donner a son lyrisme une couleur réligieuse. ${ }^{8}$

Both again illustrate the dangers of the focus on the unity of the individual poem: it creates the illusion that one part of a poem provides the predominant meaning. For Dacier the near-fatal fall of a tree can hardly be the real subject, when weighed against the delights of lyric predecessors, and the need to decide which to emphasize has been a recurrent motif in later criticism too - but surely both are the poet's subject! And for Villeneuve there was a need to find, not one subject, but one tone: Sappho and Alcaeus are serious models for Horace, so the rest of the poem must be serious too. The adverb évidemment is a give-away here, one of those words we use to control the argument when we do not want to reason the case out. It is by no means evident to me that the submissive Cerberus and poetically refreshed snakes of 33-6 are serious. But there may still be a serious meaning to Horace's play.

Eduard Fraenkel's insistence on the exclusive unity of the Ode played a part in a 2005 essay by Joseph Farrell on where Latin studies were then. As he says, ${ }^{9}$ there is an almost comical oddity in the way that Fraenkel, the committed setter of Horace within historical and generic contexts, so strongly associates himself with the 'New Critical' position that the 'poem is self-sufficient' and 'the critic's task is to interpret what is on the page'. Fraenkel was right, I believe, to warn against supposing that certain kinds of additional information would have suddenly clarified poems that are difficult to understand: we have no reason to think the meaning of an Ode ever depended on a 
title, ${ }^{10}$ or, for example, the knowledge that Postumus' prospective heir was an entirely sober youth most unlikely to drink, never mind to spill, wine (I invent, of course). But Horace could expect readers to be familiar with other external material, whether earlier texts or historical circumstances, as Fraenkel himself frequently demonstrated.

After this historical introduction, my purpose is not to examine in further detail the undoubted strengths and the weaknesses of this traditional method that stresses the unity of the individual Ode, but rather to draw to attention to a more fundamental problem: in a number of cases we do not know where the poems begin and end. I'm thinking primarily of the sequences of 'poems' in the same metre (1.16-17, 26-7, 34-5; $2.13-15,19-20$; 3.1-6, 24-5; 4.14-15); ${ }^{11}$ but one might also wonder about dividing some poems that are numbered as units. Here I shall consider how the sequence of three Alcaic pieces, 2.13, 2.14, 2.15 are currently read, and how they would be read differently if the case for combining them as one were accepted.

7 To start, 2.13. This begins with twelve lines of imprecation on the planter of the dangerous tree, fantastically imagining that it was his intention to kill his descendants and disgrace the neighbourhood. Then 8 lines of moralizing about the ever-present possibility of dying; and, with verse 20 , closure:

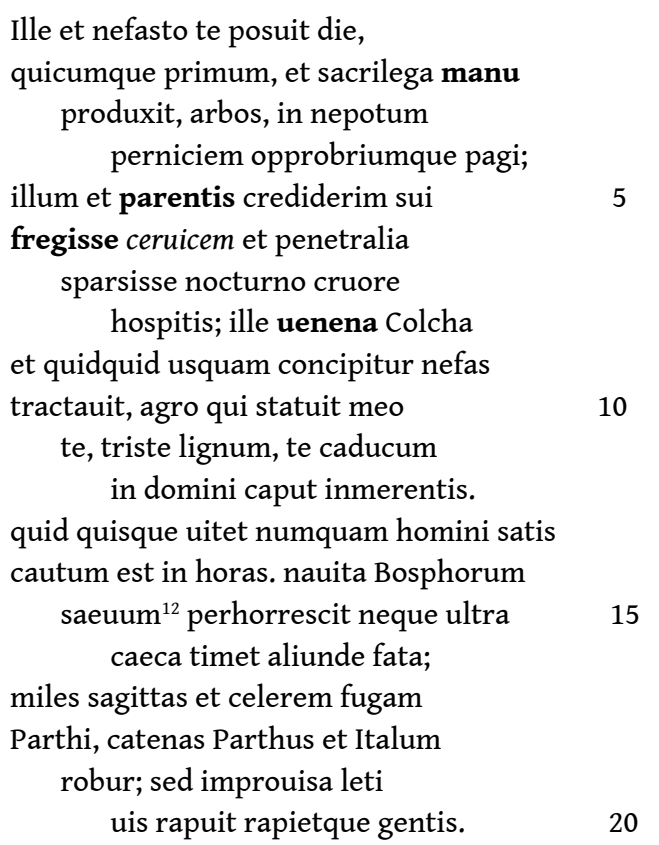

He planted you on an evil day, whoever first did so, and raised you with a sacrilegious hand, o tree, for the destruction of descendants and as a disgrace for the parish; that he broke the neck of his own father I am willing to believe, and spattered the household shrine with the blood of an overnight guest; he handled the poisons of Medea and whatever wickedness is conceived anywhere, the man who established you on my farm, you sorry piece of timber, destined to fall on the head of an undeserving master. Man has never sufficiently taken care from hour to hour what each should avoid. The sailor shudders at the wild Bosphorus and does not beyond it fear unseen death from other causes, the soldier fears the arrows and swift flight of the Parthian, the Parthian Italian chains and might; but the unexpected force of death has carried off whole races and will carry them off.

But this is false closure, and the poem continues with the Sappho and Alcaeus scene Horace so nearly saw in the Underworld. Stephen Harrison nicely describes the sequence: 
In structure, the poem falls into two clearly marked halves: 1-20 on the poet's narrow escape from the tree a comic curse followed by moralising about the everpresent possibility of dying, and 21-40 on what the poet would have seen had he in fact gone down to the underworld. ... This is one of a number of odes in which there is a clear thematic change in the middle and even an apparent false closure (see Harrison 2004) ${ }^{13}$; at line 20 the poem seems to be over, since the humorously exaggerated curse on the tree and reflections on death reach a natural conclusion ... As in 2.5, this element of false closure is aided by the epigrammatic tradition on which the poem draws: 1-20 look back to two types of Greek epigram - the dedicatory epigram recording or giving thanks for an escape from death ... and the sepulchral epigram, to which the apparently concluding moralising about the universal and sudden rapacity of death (13-20) looks back .... Poetic closure seems accomplished; ... we seem to have a complete epigram at the maximum length of twenty lines. But the idea of death is then neatly deployed to continue the poem with the poet's potential tour of the underworld. ${ }^{14}$

8 The opening curse adopts an iambic posture, and reinforces this with specific allusion to the joky curse at the start of the third Epode:

Parentis olim siquis impia manu senile guttur fregerit,

edit cicutis alium nocentius.

o dura messorum ilia.

quid hoc ueneni saeuit in praecordiis? ${ }^{15}$

If any has ever crushed the elderly throat of his father with evil hand, let him eat garlic, more harmful than hemlock. How tough were the innards of the harvesters!

What kind of poison is this that rages in my stomach?

Commentators have made good use of the connexion: ${ }^{16}$ whereas the Epode continues in curse mode, in the Ode Horace uses his histrionic anger as a starting point. Davis is good on the structure: ${ }^{17}$ he argues that the sententious speaker of $13-20$ transcends the iambographic voice of the start: the evil planter of the tree matches the sinners punished in the underworld in the closing stanza, those who offended against the Olympians, while Horace himself matches Sappho and Alcaeus:

quam paene furuae regna Proserpinae

et iudicantem uidimus Aeacum

sedesque discretas piorum et

Aeoliis fidibus querentem

Sappho puellis de popularibus,

et te sonantem plenius aureo,

Alcaee, plectro dura nauis,

dura fugae, mala dura belli.

utrumque sacro digna silentio

mirantur umbrae dicere, sed magis

pugnas et exactos tyrannos densum auida ${ }^{18}$ bibit aure uolgus.

quid mirum, ubi illis carminibus stupens

demittit atras belua centiceps

auris et intorti capillis

Eumenidum recreantur angues?

quin et Prometheus et Pelopis parens

dulci laborem decipitur sono,

nec curat Orion leones

aut timidos agitare lyncas.

40

How nearly we saw the kingdom of dark Proserpina and Aeacus judging and the separate abode of the good and, singing sorrowfully to the Aeolian lyre, Sappho, on the girls from her country, and you, Alcaeus, sounding more strongly with your 
golden plectrum, on the hardships of sea-going, hardships of flight, unpleasant hardships of war..$^{19}$ The shades admire both as they say things that deserve sacred silence, but it is rather the fights and the driving out of tyrants that the dense crowd drinks in with eager ear. What wonder, when, stupefied by those songs, the hundred-headed beast lets its ears droop and the snakes twisted into the hair of the Eumenides are refreshed? Nay, even Prometheus and the father of Pelops are beguiled in their labour by the sweet sound, and Orion does not bother to chase lions or fearful lynxes.

By the end, Davis says (88), the 'angry iambic speaker ... has given way to the superior lyric voice'. Commager similarly found a way to integrate the parts of the poem: ${ }^{20}$ 'In singling out Sappho and Alcaeus to represent the underworld, Horace does more than pay tribute ... The timeless popularity of the two suggests, however fancifully, their triumph over, if not escape from, the improvisa leti vis (19-20). If the parody of the first three stanzas is designed to reduce the incident of the fallen tree to manageable size, the scene in Hades attempts to answer it directly.' Denis Feeney characteristically problematizes the concentration on Alcaeus's grander style, and sees it as part of the preparation for the Roman Ode(s). ${ }^{21}$

Modern interpretation thus seems to me to have overcome with great success the objections to the poem's lack of unity that Jani responded to in his Argumentum (\$2). Yet we would be wise to acknowledge that this is a discursive unity, as Jani himself saw (§1); and we should remember that Horace is creating a version of Greek lyric in Latin. Pindar is the only Greek lyric poet for whom we have enough whole poems to comment on structural norms, and he is famous for his digressiveness and abrupt transitions; but one might say that Horace rejects him as a model (even in 4.2), and in any case he is not writing epinicia. However, even in the case of Alcaeus and Sappho, some of the fragments hint at decisive changes of direction (e.g. Alcaeus frr. 73, 117(b)), and here too, there are tricky questions about where poems begin and end (e.g. Sappho's Tithonus poem).

The opening of poem 14 includes a vocative, like many of the Odes; after the regretful Eheu and the plangent repetition of the evocative name Postumus, we are straight into observations on the inevitability of the passing of time - and the coming of death: we revert to a theme of 2.13; and this takes over as the main theme in what follows (no more is said on the signs of old age). Harrison emphasizes the continuities with 2.13 , in observant detail:

The topic of death pairs this poem closely with the contiguous 2.13 , which likewise points to the inevitability of death $(2.13 .13-14 \sim 2.14 .1-12)$, specifies sailing as perilous for mortals $(2.13 .14-15 \sim 2.14 .13-14)$, and gives some account of the mythological topography of the underworld (2.13.21-40 2.14.7-9, 17-20); there is nice irony in 2.13's focus on escape from death being followed by 2.14 's insistence on its universality....

The poem falls into two clear parts, the first describing the general necessity of death in one sentence of three stanzas (1-12), the second recounting the particulars of its possible modes and consequences in two sentence of two stanzas each (13-28). ... The poem ends with two stanzas of items that must be left behind, listed with increasing specificity, climaxing in the trees of 22-4 and then followed by a whole stanza on wine (25-8). ${ }^{22}$

Like earlier commentators he also notes the link with 2.3 , especially $17-20$ where thoughts of a rich man's inevitable death (the poem is addressed to moriture Delli) lead on briefly to the heir who will take possession of the estate. But when Harrison's analysis of the structure of 2.14 calls the last two stanzas 'a sentence', he ignores the 
change of topic and lack of connexive in 25-8: more reasonably, Woodman saw stanzas 1-3 and 4-6 as going together in two groups, 'with the seventh standing apart'. ${ }^{23}$ Horace's phrasing makes shift of attention from the moribund dominus to the heir a radical move, not to be set aside with light punctuation:

frustra cruento Marte carebimus

fractisque rauci fluctibus Hadriae,

frustra per autumnos nocentem corporibus metuemus Austrum:

uisendus ater flumine languido

Cocytos errans et Danai genus

infame damnatusque longi Sisyphus Aeolides laboris;

linquenda tellus et domus et placens

uxor, neque harum quas colis arborum

te praeter inuisas cupressos

ulla breuem dominum sequetur.

absumet heres Caecuba †dignior $\dagger$

seruata centum clauibus et mero

tinget pauimentum superbo, pontificum potiore cenis.

In vain shall we avoid bloodthirsty Mars and the choppy waves of the roaring Adriatic, in vain shall we fear the South Wind that harms the body every autumn: we must go and see the black Cocytus, meandering with slow stream, and the infamous offspring of Danaus, and Sisyphus, son of Aeolus, condemned to long labour; the earth must be left behind and the home and the agreeable wife, nor of the trees you cultivate here shall any follow their brief master besides the hated cypresses. A tworthiert heir will use up the Caecuban preserved by a hundred keys and will bathe the floor with a grand wine, too rich for the dinners of the pontiffs.

11 Woodman's article is rather long, but remains useful. He sets aside Dahl's simplistic, unifying reading ${ }^{24}$ which hunts through the poem for any hint of liquid; he notes the link that dominum in verse 24 makes with 2.13 .12 and 2.15.8; and at the end he argues well that dignior must be corrupt in 25 , and probably superbo in 27 too. Heirs are traditionally greedy spendthrifts in literature, as at Odes 3.24.61-2 indignoque pecuniam/ heredi properet; and 4.7.19-20 cuncta manus auidas fugient heredis amicol quae dederis animo. ${ }^{25}$ Nisbet \& Hubbard find a pointed paradox here; but such a paradox would need to be clarified by the context. On the contrary, we are told only that the heir uses up the fine wine (and absumet has a connotation of squandering: OLD 1) and, worse, he spills it on the floor. Though (in verse 26) there is a satirical edge to the hundred keys that currently keep the prized vintages safe, the Horace who hymns the delights of properly aged wine can hardly be the man to attack an addressee for doing just that. Campbell's degener, with its similarity of form and aptness in phrasing, looks an excellent correction: ${ }^{26}$ though Horace nowhere else uses the word, it is quite rare in verse (2 instances in Vergil, 3 in all of Ovid, e.g.), but entirely fitting here: cf. Vergil, Aeneid 2.549 degeneremque Neoptolemum, Germanicus, Arat 127; and Curtius 4.12.11 degeneres et patrii moris ignari. The poem now lacks 'the characteristic paraenesis' Nisbet \& Hubbard seek; but it may be that the function of the material is different here. As for superbo, mero has a second epithet in potiore in the final line, and superbus is not obviously apt for the wine; superbum (Lambinus) would be slightly odd of a floor, and (as Bentley pointed out) gives the text three consecutive words ending in -um; Lynford's superbis gives exactly what we needed, knitting together the phrases and enhancing the grandeur of the wasted wine: 'a degenerate heir will use up the 
Caecuban preserved by a hundred keys and will bathe the floor with a wine too rich for the grand dinners of the pontiffs.'

12 Commentators and translators ${ }^{27}$ usually treat harum in 22 as deictic, evoking a scene on a country estate or in the garden of a suburban villa; but in context it may be easier to take the implication to be 'here, in the upper world' (OLD 2c), in contrast to the underworld scene described in 17-20. Pasquali is one scholar who has drawn attention to the way this stanza reworks Lucretius 3.894-6:28

Iamiam non domus accipiet te laeta neque uxor

optima, nec dulces occurrent oscula nati

praeripere ...

Any time now your home will not welcome you happily, nor your wife, excellent as she is, nor will your delightful children run to snatch kisses, ...

non domus ... neque uxor optima are neatly inverted by et domus et placens uxor. As so often in close imitation the point may come in the change. No attention is here paid to children, though Commager (1962: 286) speaks extraordinarily of 'the plaintive farewell to wife and child'. Instead the focus is moved to trees, and we have another link with 2.13 .

13 As it stands, 2.15 is a poem without addressee or occasion; it simply begins with an announcement of the imminent destruction of the whole agricultural landscape, apparently of Italy, but not even that is specified. There is no present verb in the whole poem: we move from the description of the decadent future in 1-10 to the contrasting commonwealth of the past in 10-20:

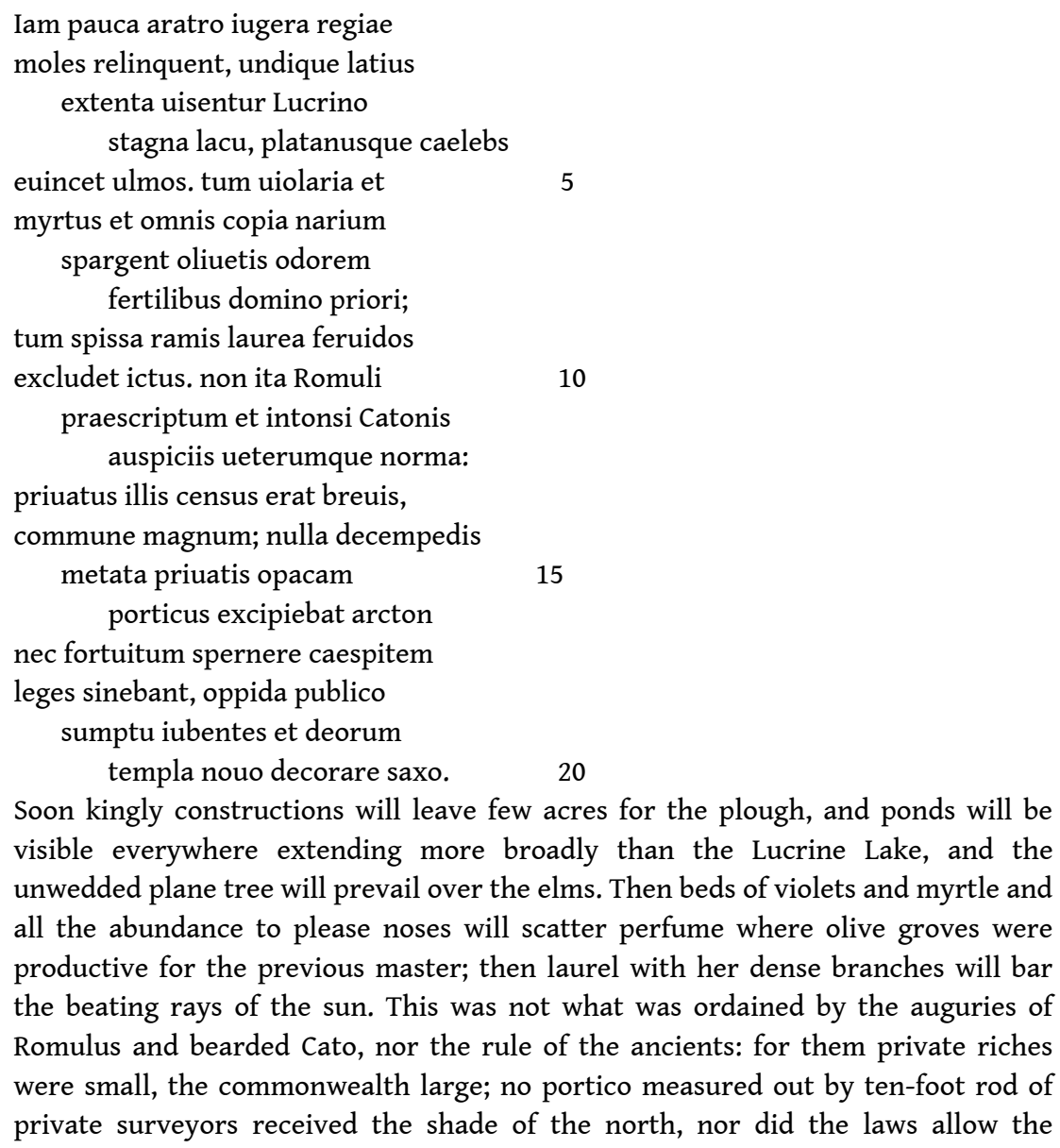

Soon kingly constructions will leave few acres for the plough, and ponds will be visible everywhere extending more broadly than the Lucrine Lake, and the unwedded plane tree will prevail over the elms. Then beds of violets and myrtle and all the abundance to please noses will scatter perfume where olive groves were productive for the previous master; then laurel with her dense branches will bar the beating rays of the sun. This was not what was ordained by the auguries of Romulus and bearded Cato, nor the rule of the ancients: for them private riches were small, the commonwealth large; no portico measured out by ten-foot rod of private surveyors received the shade of the north, nor did the laws allow the 
disdaining of turf happened upon, when they ordered adorning towns at public expense and the temples of the gods with unused stone.

Barber brings out the oddities: ${ }^{29}$ 'As for 2.15 , an odd bout of detached moral outrage, the lack of address is perhaps as puzzling as in 1.34, although here, also exceptionally, the poet offers no hint of a first-person speaker; the poem reads like a snippet of a satire rather than a fully developed ode.' This is not a well-loved poem, unlike 13 and 14. Scholars (e.g. Nisbet \& Hubbard) have seen it as foreshadowing the Roman Odes; Kiessling thought it might be a fragment that never found a home there; and Campbell went as far as to transpose it to become the start of 3.6. ${ }^{30}$

Others emphasize the links with what has preceded - and here I start to move to the case for the other way of reading the sequence. It is a fact that not only some editions (as Watson has it), but a major portion of the MS tradition, including the oldest R, do not indicate a division here. Continuity of text is also the implication of the commentary attributed to Acro, and all three writers on metre, Diomedes, Servius, Victorinus, who list each ode in metrical groups. In other words, the balance of MS evidence, for the little it is worth, is that 2.14 and 2.15 are one (and there is evidence too of continuity between 2.13 and 2.14, though R is the only MS I know of not to make a division at Eheu fugaces).

Watson brings in a mighty opponent for the direct and indirect evidence: Common Sense, which 'shews the Subject and Scope, and therefore the Odes, to be quite different'. It is true that the second half of the poem moves on to public policy; but in the first half the first person plural that Watson uses to generalize his translation is entirely absent from the Latin. This may be fair if the poem is independent, but such intrusions can hardly the determine the 'subject and scope' if the lines are continuous. Some scholars have found continuity, though of a literary, rather than a textual kind. Thus Sturtevant: ${ }^{31}$ 'The last stanza of 14 refers to the growing luxury of the day, and that is the theme of 15.' It is part of the strategy of Santirocco's account of the Odes to find links between adjacent poems, and he observes: 'The powerful image of extravagance with which $C$. 2.14 closes - the prodigal heir wasting wine on the pavement- makes an elegant transition to C. 2.15 , which is all about extravagance.' He even notes that the MSS run the poems together, but treats this as a coincidence. ${ }^{32}$

In my 1995 paper on the ways in which Latin poems are divided in our MSS, I drew attention to the frequent errors of omission and commission in the handling of segmentation. Moreover, the further back we go in traditions such as Catullus, ${ }^{33}$ Propertius, Ovid's Amores, and Horace, the fewer markers of division to be found. The evidence thus suggests that divisions were generally lost in these traditions, and then re-introduced gradually by conjecture: no more weight is to be given to manuscript markers of separation than to manuscript punctuation; the editing of divisions needs to be approached radically. In the case of the Odes I suggested that there is a convenient short-cut: a new ode begins only when a new book begins or the poet changes metre. Two decades later I am increasingly convinced this is right. This is not because of an overwhelmingly favourable response (though Griffiths 2002 and Barber 2012 have argued for amalgamations in books 1 and 3): but partly because the individual cases seem to me to work, and partly because of a point I understated in the original paper. It is an extraordinary feature of the sequences that this theory would amalgamate that in no case does the presence of conflicting addressees prevent our reading the poems as single units. In some instances there is a movement between individual addressees and a collective (1.26-7), or between gods and mortals (3.1-6), but these are features found 
in the canonical units, and not signs of separation. ${ }^{34}$ Those who maintain the traditional numeration have to face the oddity that in no case where Horace might have foreseen false amalgamation has he prevented this by using distinct addressees, i.e. different individual human beings. There are 35 poems (out of 103 in the canonical count) that simply on the basis of addressees (or quasi-addressees, such as Vergil in 1.3) could not be amalgamated with the ode before or after; these include none of the 21 'poems' that are adjacent pieces in the same metre. In most other cases there is a clear separation of subject matter: even if metre were set aside there is no case for thinking that the sequence of three sympotic odes 1.36-8 (the return of Numida from Spain; celebration of the downfall of Cleopatra; simple pleasures) could be other than three separate poems. But for the poems that continue the metre there is never a clash of addressee; indeed twice - and this occurs nowhere besides two cases of shared metre: 3.3-4, 4.14-15 - there is continuity of addressee). Always there is at least a superficial continuity of theme. By a chance that is on the conventional view extraordinary none of the metrically grouped poems falls in a sequence like $2.6-12$ or $4.7-13$, where the change of addressee clearly indicates discontinuity poem by poem.

To return to the reception of the theory: there have been polite footnotes rejecting the possibility in papers by Hutchinson and Faber. ${ }^{35}$ Nisbet \& Rudd rejected the idea for the Roman Odes on the grounds including that 'the dates of the odes are different'. ${ }^{36}$ This assertion is frankly unworthy of two important scholars, but I shall linger on it a moment because it involves a regularly neglected point of method: in the first place, they cannot know the dates - these are hypotheses, not data; and, more importantly, even if they knew the date for the composition of a single verse, sentence or stanza, that would not establish a date for the whole of the unit within which it is published. There is no reason to think even quite short lyric poems were regularly written by Horace at a single sitting - he is after all the writer who in the Ars Poetica urges setting poems aside till the ninth year, and taking the advice of a good iudex (387-90). Nor is there any weight in arguments that Horace cannot have written a 336-verse ode (as I pointed out in 1995): the uniqueness of the sequence is not in question, given that Horace nowhere else has a run of 84 stanzas in the same metre; and there are two significant parallels for a poem that is far longer than what surrounds it: Pindar, Pythian 4, and Horace, Sermones 2.3. Nor do any parts of the poem reveal a clear enough sense of occasion for there to be an internal conflict when we read it as a unit.

Perhaps the most thoughtful response comes at the end of Murgia's paper on the division of Propertius ' 2 '. ${ }^{37} \mathrm{He}$ found merit in the theory, but doubted that it could apply in certain cases, particularly $2.13-15$ and $4.14-15 .{ }^{38} \mathrm{He}$ wrote: 'I would find it difficult to join 2.13-15 as one long Alcaic poem: 13 can be conceived as leading into 14, but 15 works on a different theme, on the invasion of luxury in Roman society, ... It is not true (despite Heyworth 145) that "2.15 develops the description of what will happen to wealth after death"; Horace talks of the direction in which luxury is heading in Rome (unrelated to anyone's death).'

19 However, the formulation of the theme in 15 depends on whether the poem begins with a sudden assertion about the destruction of the overwhelming majority of agricultural land in an unspecified area - which Murgia, and the commentators assume to be Italy at large, absurd though the assertion is - or rather the sequence of futures continues the account of what will happen to the dying man's estate after his death (2.14.25-15.10): 


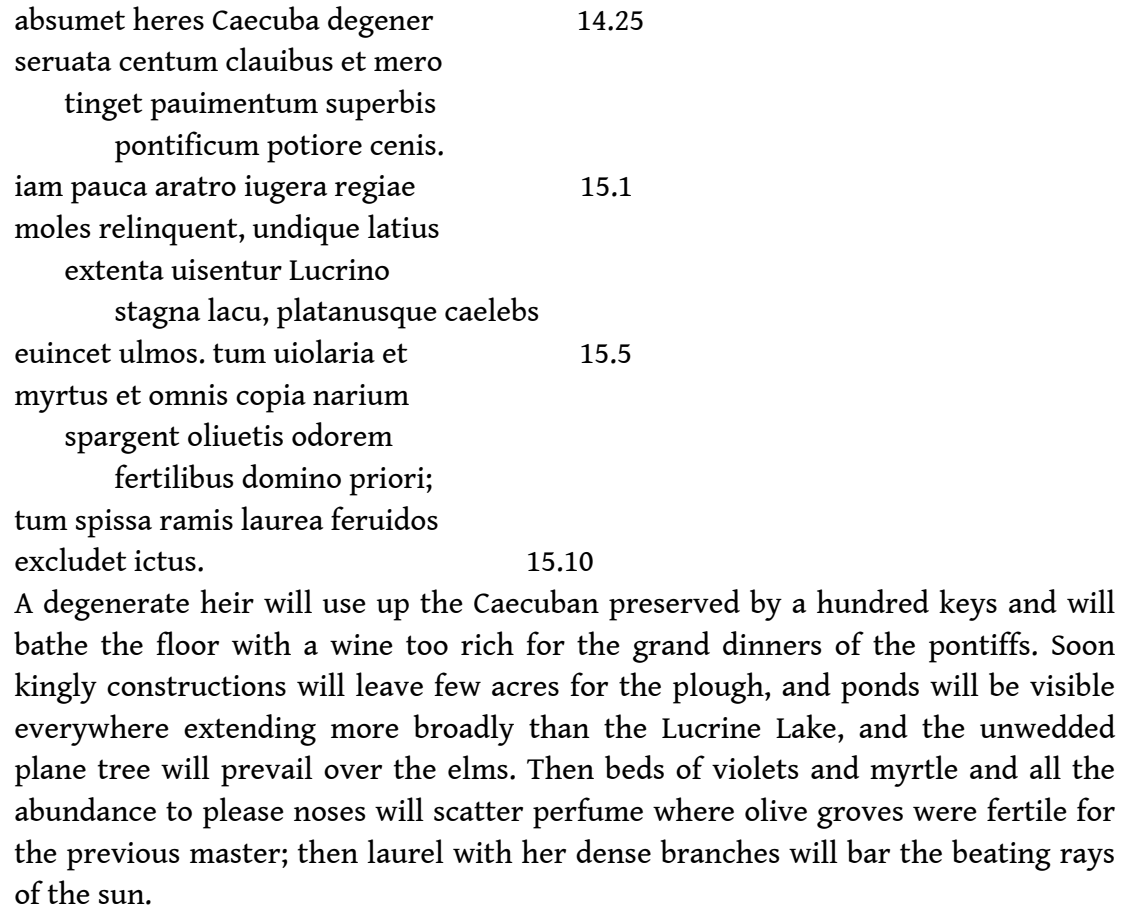

A degenerate heir will use up the Caecuban preserved by a hundred keys and will bathe the floor with a wine too rich for the grand dinners of the pontiffs. Soon kingly constructions will leave few acres for the plough, and ponds will be visible everywhere extending more broadly than the Lucrine Lake, and the unwedded plane tree will prevail over the elms. Then beds of violets and myrtle and all the abundance to please noses will scatter perfume where olive groves were fertile for the previous master; then laurel with her dense branches will bar the beating rays of the sun.

Another objection raised by Murgia concerns iam: 'its initial word, Iam, ${ }^{39}$ has a temporal reference ("soon") which cannot be related to the time frame of the last stanza of 14: it thereby establishes a break.' Though this claim is made with unqualified confidence by a fine scholar, I cannot see that it is based on a careful examination of evidence. On iam with future in general, the Thesaurus omits many instances at 105.19-106.14, and does not really help clarify the patterns. But consider the following passages where iam occurs within a run of futures. At Vergil, Ecl. 4.34-45, iam in verse 41 continues the prophetic sequence without marking a break; and though iam ... iam in 43-4 is equivalent to modo ... modo, the choice of the same adverb seems designed to promote continuity.

alter erit tum Tiphys et altera quae uehat Argo

delectos heroas; erunt etiam altera bella 35

atque iterum ad Troiam magnus mittetur Achilles.

hinc, ubi iam firmata uirum te fecerit aetas,

cedet et ipse mari uector, nec nautica pinus

mutabit merces; omnis feret omnia tellus.

non rastros patietur humus, non uinea falcem;

robustus quoque iam tauris iuga soluet arator.

nec uarios discet mentiri lana colores,

ipse sed in pratis aries iam suaue rubenti

murice, iam croceo mutabit uellera luto;

sponte sua sandyx pascentis uestiet agnos.

Then there will be another Tiphys and another Argo to carry chosen heroes; there will be a second round of wars and again mighty Achilles will be sent to Troy. Then, when strengthened maturity has already made you a man, even the traveller will abandon the sea, nor will the pine-wood boat trade goods: every land shall bear everything. The ground will not endure mattocks, nor the vine the pruning hook. The hardy ploughman too will take the oak from his oxen now, and wool will not be taught to put on a pretence of varied colours, but the ram in the meadow will himself now exchange its fleece for sweetly reddening purple, now for saffron yellow. Vermilion will naturally clothe the pasturing lambs.

And similarly in Aeneid 1.267-74: 
at puer Ascanius, cui nunc cognomen Iulo additur (Ilus erat, dum res stetit Ilia regno), triginta magnos uoluendis mensibus orbis imperio explebit, regnumque ab sede Lauini transferet, et Longam multa ui muniet Albam. hic iam ter centum totos regnabitur annos gente sub Hectorea, donec regina sacerdos Marte grauis geminam partu dabit Ilia prolem.

The boy Ascanius, to whom the name Iulus is now given (he was Ilus, while the Ilian state stood in power), will fill out with his reign thirty great cycles of onwardrolling months, and will transfer the kingdom from the seat of Lavinium and powerfully fortify Alba Longa. Here subsequently there will be three hundred complete years of rule by Hector's race until the royal priestess Ilia, made pregnant by Mars, will give birth to twin offspring.

Ovid, Amores 1.4.61-4 is trickier, because iam is repeated, but the adverb still marks an ongoing sequence of future events.

nocte uir includet, lacrimis ego maestus obortis, qua licet, ad saeuas prosequar usque fores.

oscula iam sumet, iam non tantum oscula sumet: quod mihi das furtim, iure coacta dabis.

At night your husband will lock you in, and I shall sadly follow as far as I may right to the door while tears fall. Soon he will take kisses, soon he will take more than kisses: what you give me in secret you will give him forced by his rights.

Odes 2.20.1-16 is also of relevance, even though the verbs immediately before iam uisam in 13-14 are not futures; for scholars have shown that iamiam even with the present refers to things that are going to happen any moment now. ${ }^{40}$ iam in 13 marks a later stage, but again does not establish a break.

Non usitata nec tenui ferar

pinna biformis per liquidum aethera

uates neque in terris morabor

longius inuidiaque maior

urbis relinquam. non ego, pauperum

sanguis parentum, non ego, quem uocas,

dilecte Maecenas, obibo nec Stygia cohibebor unda.

iam iam residunt cruribus asperae

pelles et album mutor in alitem

superne nascunturque leues per digitos umerosque plumae.

iam Daedaleo notior Icaro

uisam gementis litora Bosphori

Syrtisque Gaetulas canorus ales Hyperboreosque campos;

I shall be borne on no common or slight wing, a two-formed poet, through the pure air, and not linger longer on the earth, but too mighty for envy I shall leave the cities behind. I, the son of poor humble parents, I, whom you summon, loved Maecenas, shall not die, nor shall I be constrained by the waters of the Styx. Rough skin is imminently gathering on my legs and I am to change into a white bird from above, and light plumage to be produced along my fingers and across my shoulders. Soon, more famous than Daedalus' son Icarus, I shall visit the shores of the lowing Bosphorus, the Gaetulian Syrtes and the plains of the distant North, a tuneful bird. have to mean 'soon' in 2.15.1 either - if it is the continuation of 2.14 : 'next' or 
'subsequently' works fine in the run of lines. On the other hand there are instances where iam marks a new poem in the Odes ${ }^{41}$ and Epodes:

carm. 1.1/2:

quodsi me lyricis uatibus inseres, sublimi feriam sidera uertice.

Iam satis terris niuis atque dirae

grandinis misit pater et rubente

dextera sacras iaculatus arcis terruit urbem, ...

But if you will insert me among the lyric bards, I shall strike the stars with a head held high.

Enough now is the snow and terrible hail that Jupiter has sent to the earth and terrified the city, aiming at the sacred citadels with hand flashing red.

Epodes - 15/16:

heu heu, translatos alio maerebis amores, ast ego uicissim risero. $\|$

Altera iam teritur bellis ciuilibus aetas, suis et ipsa Roma uiribus ruit.

Alas, you will grieve that love has been transferred elsewhere, while I shall laugh in turn.

Another age is now being worn away by civil wars, and Rome rushes to destruction through her own might.

In each case the iam is accompanied by a change of tense - just the sort of interruption of 'sequence' that Murgia's thoughtful approach has required.

One question one might raise is whether the vocative addressing the poem to Postumus comes too late, after 41 verses (out of 88 ). There has been some analysis in the article by Barber of Horace's variation of the norm by which vocatives come early. ${ }^{42} \mathrm{He}$ looks at the way the move to Fortuna ( $O$ diua gratum quae regis Antium) is handled in 1.34-5. But for now the significant point is that the corpus has plenty of instances where the main, or human addressee only appears in the second half (whereas here we are not even half way through):

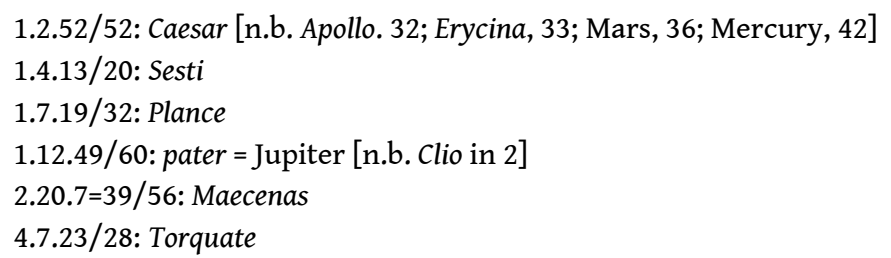

In two of these poems, moreover, we find the decisive breaks sometimes present in the middle of Odes. So striking is the change from the celebration of cities after verse 13 in 1.7 that a separation is marked in most MSS (whose scribes and readers are having to work out where the divisions should be made in the corpus), though the poem continues without break in the oldest MS R (as is usual), and in Porphyrio's commentary:

Laudabunt alii claram Rhodon aut Mytilenen aut Epheson bimarisue Corinthi

moenia uel Baccho Thebas uel Apolline Delphos insignis aut Thessala Tempe;

sunt quibus unum opus est intactae Palladis urbem carmine perpetuo celebrare

indeque $^{43}$ decerptam fronti praeponere oliuam; plurimus in Iunonis honorem

aptum dicet equis Argos ditisque Mycenas: 
me nec tam patiens Lacedaemon

nec tam Larisae percussit campus opimae quam domus Albuneae resonantis

et praeceps Anio ac Tiburni lucus et uda mobilibus pomaria riuis. \|

albus ut obscuro deterget nubila caelo saepe Notus neque parturit imbris

perpetuos, sic tu sapiens finire memento tristitiam uitaeque labores

molli, Plance, mero, seu te fulgentia signis castra tenent seu densa tenebit

Tiburis umbra tui. Teucer Salamina patremque

cum fugeret, tamen uda Lyaeo

tempora populea fertur uinxisse corona sic tristis adfatus amicos:

'quo nos cumque feret melior fortuna parente, ibimus, o socii comitesque.

nil desperandum Teucro duce et auspice Phoebo. ${ }^{44}$ certus enim promisit Apollo

ambiguam tellure noua Salamina futuram. o fortes peioraque passi
10

mecum saepe uiri, nunc uino pellite curas: cras ingens iterabimus aequor.'

Others praise glorious Rhodes, or Mytilene, or Ephesus, and the walls of Corinth between the two seas, or Thebes famous for Bacchus, or Delphi famous for Apollo, or Tempe in Thessaly; some produce a single work, celebrating in unbroken [and everlasting] song the city of virginal Pallas, and place on their forehead the olive branch plucked from there; many a one will hymn, in Juno's honour, Argos suited to horses and wealthy Mycenae: for my part I am not smitten so much by enduring Sparta or the fertile plain of Larisa, as by the home of the resounding Albunea and the waterfalls of the Anio, the grove of Tiburnus and the orchards irrigated by the shifting streams.

As the fair South Wind often wipes the clouds from the sky and does not produce rain for ever, so you should remember like a philosopher to put an end to sadness and the toils of life, with the pleasures of wine, Plancus, whether the camp gleaming with standards holds you or in future the dense shade of your estate at Tibur. When Teucer was in exile from Salamis and his father, he is still said to have bound his temples, moistened by wine, with a poplar wreath, and thus to have addressed his sad companions: 'Wherever fortune (kinder than my father) will take us, we shall go, comrades and friends. There is no reason for despair under the leadership of Teucer and the guidance of Phoebus. For Apollo clearly promised that there will be an uncertain Salamis in a new land. Brave men, you who have often suffered worse, along with me, for now drive away your cares with wine: tomorrow we shall plough the vast ocean.'

Meineke's Law (which has Horace writing Odes in multiples of 4 lines) discourages editors from following the majority of MSS here; and so does the repeated mention of Tibur $(12-14,21)$ - and of course the continuity of the metre, though that can hardly be an argument for those who willingly split other units in the same metre.

As far as I know, there is no sign of division in the MSS at 1.4.13, but here the break is (if anything) more striking: the twelve lines on spring end on the closural note of sacrifice (think of immolat at Aeneid 12.949);

Soluitur acris hiems grata uice ueris et Fauoni trahuntque siccas machinae carinas,

ac neque iam stabulis gaudet pecus aut arator igni nec prata canis albicant pruinis. 
iam Cytherea choros ducit Venus imminente luna, iunctaeque Nymphis Gratiae decentes

alterno terram quatiunt pede, dum grauis Cyclopum

Volcanus ardens uisit officinas.

nunc decet aut uiridi nitidum caput impedire myrto aut flore terrae quem ferunt solutae;

nunc et in umbrosis Fauno decet immolare lucis, seu poscat agna siue malit haedo. \|

pallida Mors aequo pulsat pede pauperum tabernas regumque turris, o beate Sesti.

uitae summa breuis spem nos uetat inchoare longam; iam te premet nox fabulaeque Manes

et domus exilis Plutonia; quo simul mearis, nec regna uini sortiere talis nec tenerum Lycidan mirabere, quo calet iuuentus nunc omnis et mox uirgines tepebunt.

Bitter winter's grip is loosened by the pleasant turn of spring and the West Wind, and contraptions drag dry keels, and the flock no longer delights in the stable nor the ploughman in the fire, nor do the meadows grow white with hoar-frost. Now Cytherean Venus leads the dancing beneath an overhanging moon, and the fair Graces joined with the Nymphs make the earth shake with dancing feet, while burning Vulcan visits the weighty workshops of the Cyclopes. Now it is right to bind a well-barbered head with green myrtle or the flowers the opened lands produce; now to sacrifice to Faunus in shaded groves, either, if he asks, with a lamb, or, if he prefers, with a kid.

Pale death kicks equally at the shacks of the poor and the towers of kings, happy Sestius. The brief sum of life prevents our establishing long hopes; soon night will press upon you, and the Manes of fable, and the ungenerous house of Pluto; when you go there, you will neither win by lot the right to rule the wine-drinking, nor look with admiration on young Lycidas, for whom all the men are now hot, and soon the maidens will be too.

A new beginning then comes in verse 13 at the start of a separate stanza; the theme of death is only tangentially related to earlier lines, indeed the thematic sense of separation is far more overt than that which divides 2.14 from 2.13. And yet editors seem not to consider breaking these two epigrammatic units into two. They can hardly be worried about disrupting the number of poems in the first book: 38 is a number in which no one has plausibly found significance. On the contrary, those like Griffiths ${ }^{45}$ who hanker after books of poems that are multiples of ten, or failing that five, should leap on this pair $(1.4,1.7)$ and restore to Horace the 40 poems that would neaten everything up, with 20 in book 2 and 30 in book 3 . The trouble is that, though there was a practice of producing 10-poem books in the 30s (Eclogues, Satires 1, Tibullus 1), it does not clearly continue, and the only firm case for a 20 -poem book is Epistles 1 . The easy assumption about a preference for multiple decimals in poem counts needs to be cautiously dropped. If we combine 2.13-15 and the second Alcaic sequence 19-20, Odes 2 is left with an untidy 17 poems - exactly the same number as the Epodes - and who is to say that is a less fitting parallel than Epistles 1 ?

What about structure of the 88 -verse poem? Does that work? Here is a rough analysis of the piece as I would see it, falling into four roughly equal quarters:

2.13.1-20: the poet's escape from the falling tree and moralising about the ever-present possibility of death [curse on the tree that nearly felled Horace, domini, 12]

2.13.21-40: what the poet would have seen had he actually descended to the Underworld [no trees in the underworld] 
2.14.1-24: the inevitability of death, now addressed to Postumus [only the cypress will follow the dead dominus (24) of the trees he cultivates]

2.14.25-15.20 [i.e. 24 lines]: the imminent destruction of the current owner's estate (n.b. domino, 8) [this includes the destruction of productive trees in favour of garden plants], against the rules of Romulus and Cato, which promoted the show of public wealth, not private.

Murgia (as we have seen, \$18) argues that 2.15 starts on a new theme, the invasion of luxury in Roman society. It is true that this becomes a theme, by line 10 , but Odes do not necessarily have a single theme. ${ }^{46}$ But the key point is that the force of the 2.15.1ff depends upon their context. If lines 1-10 are the opening of a new poem the reference must be general, the decline of society and its landscape. But if they continue from the end of 2.14, as the series of future verbs allows them to do, the point is rather the degradation after Postumus' death of the property he has so cherished. He cultivates trees, but only the unproductive cypress will follow him to the tomb, and under future owners the olive groves will be replaced by ornamental plants, and shrubs grown for their scent or shade. He keeps his cellar under lock and key, but an heir will waste even the choicest Caecuban. The landscape will be dominated by buildings and fishponds. This was not the way of life established by Romulus or Cato.

The fishponds that will be seen covering Postumus's estate match the Cocytos that he himself will see in the underworld (uisendus, 2.14.17; uisentur, 2.15.3); and his vision of the underworld resumes the one that Horace himself nearly enjoyed in 2.13.21-40. Postumus is faced with the inevitable loss of land, home and wife; the poet has the advantage that through death he can hope to join the poetic throng around Sappho and Alcaeus. Trees, cultivated by Postumus at 2.14.22, are revisited in 2.15.4-10; but both take us back to the planting of the tree that nearly killed Horace, another dominus (2.13.12; cf. 2.14.24, 2.15.8). At 2.13.3-4 the tree is described as planted in nepotum / perniciem opprobriumque pagi. The imagined planter has failed in his attempt; but so in Horace's later fantasy will Postumus (or the generic addressee, who has perhaps taken over by 2.14.22): the trees he lovingly cares for will be of no interest to the heres (2.14.25), who will replace them with fishponds, infertile shade and perfumed gardens as far as the eye can see (2.15.1-8). Both the wicked villain and the landlord planting for the future in fact have no control over what will transpire when they have passed on: cursed trees may fall without killing, orchards be felled without reaching fruitful maturity. Such continuities of motif and diction do not demonstrate unity (many adjacent odes have details in common), but they do enhance it, and that is important in so long and varied a poem.

When we read it as a separate poem, the iambic opening of 2.13 leads through sententious acceptance of death's inevitability to a lyric celebration in the Sappho and Alcaeus passage. That's a good poem, and makes generic sense, but Horace is now aiming for something grander, in the manner of Alcaeus as his concentration on the grander voice creates him in 2.13.26-32. As well as reflections on the need to accept death's unpredictable imminence, he can offer satire on the ills of modern society and the need for a reform that respects and restores the strengths of Rome's past. What begins with invective passes through an ostentatiously lyric vision of death on its way to the august topic of social restoration, both moral and physical in the form of temples. The evolving mix of personal and public makes this a serious precursor to the 'Roman Ode'; as there we find a flowing combination of social and ethical comment 
with personal and poetical observations (similar again is 3.24-5) One might say that Horace puts his personal goods to public use, in the very way the mos maiorum would commend.

Odes 19 and 20 are the other place in book 2 where the canonical numeration separates a unit in Alcaics. Poem 19 has Horace seeing Bacchus in the wilderness and thereby gaining the power and authority to hymn the god, as he does in lines 17 to 32 , where the poem ends. The separate 20 then describes how he will be carried above the earth on an immortal wing: he is turning into a Pindaric swan (9-12), and will fly around the empire and beyond: no need for a funeral. If we read the verses as a unit, the immortal grandeur announced in the stanzas of 20 is founded on the inspiration that the sight of Bacchus as god of poetry has given in 19. The hymn of 2.19.17-32 is a sample of what Horace is now equipped to produce (cf. 9-16); it leads from the theodicy of 2.19 to the metamorphosis of 2.20.9ff. The poet prepares for the Roman Odes with an account of his supernatural experiences and powers - just as in 3.24-5 he will look back on the themes that dominated the start of the book like a Maenad amazed at the sight of the land she has traversed. As there, the claim is both grand and amusing.

In conclusion, let me emphasize some methodological points that this paper has tried to bring out. (a) It is important to remember the uncertainty of the textual basis on which our interpretation stands, including words, but also punctuation. (b) The unit of the poem is a helpful guide in interpretation, but lyric is not an especially unified genre, and unifying readings here, as in other genres, may drain life from poems. (c) Chronology may matter for interpretation, but again we have very little sure ground to stand on; in the end the only terminus for an Horatian Ode is when it was published and even that we do not know. (d) Segmentation matters, where we begin and end the sentences in our texts and especially where we begin the poems themselves, and where we end them. ${ }^{47}$

\section{BIBLIOGRAPHY}

Agnesini, A. (2011) ‘Catull. 67.1s.: incipit della ianua o explicit della coma?’, Paideia 66: 521-40.

Barber, D. (2012) 'Address and the continuity of Horace, Odes 1.34-35', Hermes 140: 505-13

Barchiesi, A. (2005) 'Lane-switching and jughandles in contemporary interpretations of Roman poetry', TAPhA 135: 135-62

Bentley, R. (1711) Q. Horatius Flaccus ex recensione R. B. Cambridge

Campbell, A.Y. (1953) Horace's Odes and Epodes, Re-edited. $2^{\text {nd }}$ ed., Liverpool

Collinge, N.E. (1961) The Structure of Horace's Odes. Oxford

Commager, S. (1962) The Odes of Horace. New Haven

Connors, C. (1992-93) 'Seeing cypresses in Virgil’, CJ 88: 1-17 
Dacier, A. (1727) Euvres d'Horace en latin et en françois, avec des remarques critiques et historiques (10 vols). $4^{\text {th }}$ ed., Amsterdam

Dahl, C. (1953) 'Liquid imagery in Eheu fugaces', CPh 48: 240

Davidson, J. (1753) The works of Horace, translated into English prose, ... With the Latin text and order of construction in the opposite page, and ... notes, in English. $4^{\text {th }}$ ed., London

Davis, G. (1991) Polyhymnia. The Rhetoric of Horatian Lyric Discourse. Berkeley

Delz, J. (1993) 'Horatius ex Horatio emendatus (mit einem Anhang zum Gebrauch von plerumque)', MH 50: 214-222

du Quesnay, I.M.LeM. (2012) 'Three problems in Poem 66', in I.M.LeM. du Quesnay \& A.J.

Woodman (eds), Catullus: poems, books, readers. Cambridge: 153-83.

Esser, D. (1976) Untersuchungen zu den Odenschlüssen bei Horaz (Beiträge zur Klassischen Philologie 77). Meisenheim am Glan

Farrell, J. (2005) 'Eduard Fraenkel on Horace and Servius, or, Texts, contexts, and the field of “Latin Studies"', TAPhA 135: 91-102

Feeney, D.C. (1993) ‘Horace and the Greek Lyric Poets’, in N. Rudd (ed.), Horace 2000: A Celebration. Essays for the Bimillennium. London: 41-63

Fraenkel, E. (1957) Horace. Oxford

Griffiths, A. (2002) 'The Odes: just where do you draw the line?', in A.J. Woodman \& D.C. Feeney (eds), Tradition and Contexts in the Poetry of Horace. Cambridge: 65-79

Harrison, S.J. (2004) 'Lyric Middles: the Turn at the Centre in Horace's Odes', in S. Kyriakidis \& F. de Martino (eds), Middles in Latin Poetry. Bari (Collana di Studi e Testi 38): 81-102

Harrison, S.J. (2007) Generic enrichment in Vergil and Horace. Oxford

Harrison, S.J. (2017) A commentary on Horace, Odes Book 2. Cambridge

Heyworth, S.J. (1995) 'Dividing poems', in O. Pecere \& M. D. Reeve (eds), Formative Stages of

Classical Traditions: Latin Texts from Antiquity to the Renaissance. Spoleto: 117-48

Heyworth, S.J. (2012) 'The elegiac book: patterns and problems', in B.K. Gold (ed.), A Companion to Roman Love Elegy (Blackwell Companions to the Ancient World). Chichester: 219-33

Heyworth, S.J. (2015) 'Poems 62, 67, and other Catullian dialogues', in D. Kiss (ed.), What Catullus wrote: problems in textual criticism, editing and the manuscript tradition. Swansea: 129-55

Heyworth, S.J. (2016) 'Irrational panegyric in Augustan poetry', in P. Hardie (ed.), Augustan poetry and the Irrational. Oxford: $240-60$

Hutchinson, G.O. (2008) Talking Books: readings in Hellenistic and Roman Books of Poetry. Oxford

Jani, C.D. (1778) Q. Horatii Flacci Opera recensuit varietate lectionis et perpetua adnotatione illustravit M. C. D. Iani. Tomus 1 . Leipzig

Kiessling, A., \& Heinze, R. (1930) Q. Horatius Flaccus, Oden und Epoden. $7^{\text {th }}$ ed., Berlin

Lowrie, M. (1997) Horace's Narrative Odes. Oxford [esp. 199-214]

Murgia, C.E. (2000) 'The division of Propertius 2', MD 45: 147-242

Nisbet, R. G. M., \& Hubbard, M. (1978) A Commentary on Horace, Odes, Book 2. Oxford

Nisbet, R. G. M., \& Rudd, N. (2004) A Commentary on Horace, Odes, Book 3. Oxford 
Pasquali, G. (1920) Orazio lirico. Firenze

Santirocco, M.S., (1986) Unity and design in Horace's Odes. Chapel Hill

Schmidt, E.A. (2002) Zeit und Form. Dichtungen des Horaz. Heidelberg

Schmidt, E.A. (2004) 'Auf den Flügeln des Choriambs: Herder und Horaz', International Journal of the Classical Tradition 10: 416-37

Schwindt, J.P. (2004) 'Dislocatio temporis. Struktur und Ereignis in Horaz' Lyrik', in W. Lange, J.P. Schwindt, \& K. Westerwelle (eds), Temporalität und Form. Konfigurationen ästhetischen und historischen Bewußtseins. (Beiträge zur neueren Literaturgeschichte 213). Heidelberg: 77-93, at 81-5

Sturtevant, E.H. (1912) ‘O matre pulchra filia pulchrior', CR 26: 119-22

Syndikus, H.-P. (1972-73) Die Lyrik des Horaz (2 vols). Darmstadt

Travillian, T.T. (2013) 'Horace’s Odes 3.1 and 3.2: carmen or carmina?', Latomus 72: 984-96

Villeneuve, F. (1946) Horace: Odes et Epodes (Belles Lettres). $2^{\text {nd }}$ ed., Paris

Watson, D. (1741) The Odes, Epodes, and Carmen Saeculare of Horace translated into English prose ... together with the Original Latin from the Best Editions. London

West, D.A. (1998) Horace Odes II: Vatis Amici. Oxford

Wilson, P. (2009) 'Horace and eighteenth-century commentary', in L.B.T. Houghton \& M. Wyke (eds.) Perceptions of Horace. Cambridge: 271-89

Woodman, A.J. (1967) 'Eheu fugaces', Latomus 26: 377-400

\section{NOTES}

1. Schmidt 2002, esp. Chapter 19 'Hermeneutische Prinzipien bei der Exegese der Horazoden im 18. Jahrhundert' (429-84), and 180-9 on the dating of 2.13; and 2004.

2. Wilson 2009.

3. Jani 1778 , Praefatio f. vii ${ }^{\mathrm{v}}$-viii ${ }^{\mathrm{r}}$ [unnumbered].

4. Davidson 1753.

5. Watson 1741 .

6. The final sentence is a reference to the criticisms of Lord Kames, as explained by Wilson 2009: 283, n. 28.

7. Dacier 1727: vol. 2, 162.

8. Villeneuve 1946: 73f., n. 3.

9. Farrell 2005: 93.

10. Fraenkel 1957: 208.

11. Heyworth 1995: 140-5, pages which owe much to an earlier draft of Griffiths 2002.

12. saeuum Delz 1993: 219-20; Poenus MSS. See Harrison 2017: 161.

13. Harrison 2004.

14. Harrison 2017: 156. We may usefully add at this point what Schwindt brings out in his brief account of the poem (2004: 81-5): the lack of a foundational point in time - we begin in the imagined past, and end with an avowedly non-existent event in the underworld (quam paene ... uidimus); even the present tenses of 13-20 are not anchored in a fixed present.

15. Epod. 3.1-5; note also the reference to Medea in verse 10.

16. E.g. Syndikus 1972-73: 419: 'Die nächsten Parallelen dazu finden wir tatsächlich im Epodenbuch. Der Unterschied is nur der: Dort waren vergleichbare Zornausbrüche Sinn und 
Mitte der Dichtung; jetzt, in einer Ode, ist das bloß noch Ausgangspunkt, viel entscheidender wird dann das innere Wegbewegen von dem leidenschaftlichen Ausbruch sein.'

17. Davis 1991 (78-89 on 2.13).

18. auida Bentley: umeris codd.: hilari Heinsius.

19. Editors, commentators and translators generally take mala as the substantive, and dura as the adjective: but dura nauis, dura fugae are intelligible phrases, and set up the pattern before we meet mala. Given the ambiguity and the direction provided by the sequence, I find it hard to read the repeated word as an attributive adjective.

20. Commager 1962: 316.

21. Feeney 1993: 49.

22. Harrison 2017: 167-8.

23. Woodman 1967: 378.

24. Dahl 1953.

25. 'and hastens the unworthy heir getting his money'; 'everything that you give in a friendly spirit will escape the greedy hands of your heir'.

26. It is accepted also by Harrison 2017.

27. E.g. Kiessling-Heinze 1930; Nisbet \& Hubbard 1978; Harrison 2017; see also Barchiesi 2005: 155-6.

28. Pasquali 1920 (643-9 on 2.14).

29. Barber 2012: 507.

30. Nisbet \& Hubbard 1978; Kiessling \& Heinze 1930; Campbell 1953.

31. Sturtevant 1912: 122.

32. Santirocco 1986: 99.

33. There is now another instance of misplaced division in editions of Catullus to add to the list: Agnesini 2011 and du Quesnay 2012: 181-3 have shown that 67.1-2 belongs at the end of 66 (the sequence is undivided in the oldest MSS); see also Heyworth 2015: 135-7.

34. Thus Carm. 1.2 invokes Apollo and other gods before ending with te duce, Caesar in 52; 1.24 addresses Melpomene (3) and then Vergil (10); 3.14 works through o plebs (1), pueri et puellae (10), puer (a slave, 17); 4.6 moves from Apollo to uirginum primae puerique (31). Similarly in the Epodes, poem 9 addresses Maecenas (4), posteri (11), Triumphus (21-4), a slave boy (33); poem 10 addresses Auster (3-4), then Mevius (15-16). In the first half of 17, Horace addresses Canidia (6), but also o mare et terra (30).

35. Hutchinson 2008: 135, n. 13; Faber 2005; Travillian 2013 gives a more extended response, but in the end decides that 3.1 and 3.2 are a pair, a dialogue.

36. Nisbet \& Rudd 2004: xxi.

37. Murgia 2000 (239-41 are on Horace).

38. On the latter unit, see Heyworth 2016: 256-60.

39. Note the imposingly separative capital.

40. See Nisbet \& Hubbard 1978, ad loc.

41. Cf. also the transitions between 4.6 and 7, 4.11 and 12 . Not really a comparable instance is that at 4.5.2; but there is still a change of tense.

42. Barber 2012: 509. As he observes, 'the late introduction of address often accompanies a shift of thought'.

43. celebrare / indeque Bouhier: celebrare et / undique MSS.

44. Phoebo Bentley: Teucro uel Teucri MSS.

45. Griffiths 2002: 66-7. On the damage done by modern critics' urge to find multiples of ten (or five) poems, see Heyworth 2012: 220-2.

46. As Horace's Greek models did not (cf. §9). In the case of the Roman Ode, 3.1-6, there is a great knot of interwoven themes, with elegant transitions and resonances. One part of this, the so- 
called '3.2', is notably incoherent: it does not work as a unit separate from the larger whole, but it does explore a varied range of themes that ramify through the whole set.

47. Versions of this paper were presented at the meeting of the Augustan Poetry Réseau in November 2015, and at Harvard University on 13th April 2016: I am grateful to my hosts (Jacqueline Fabre-Serris and Richard Thomas) and to the audiences on each occasion, and especially to my colleagues at Lille for inspiring me to return to the topic, with methodological slant, in honour of Alain Deremetz.

\section{ABSTRACTS}

The notion of the single Ode as a unit, coherent and complete in itself, has played a long and important part in Horatian criticism, as recent research has shown. But there are dangers to this interpretive principle, partly because lyric is an expansive and digressive genre, and partly because the units into which editors divide the books are based on traditional numeration rather than the most ancient evidence and careful argumentation. The presence or absence of division necessarily has implications for our reading, as is illustrated by examination of Carm. 2.13-15. If we adopt the principle that within a book Horace begins a new Ode where he changes metre, this unit can be read as a fine exploration of interwoven themes, looking back at times to the modes of the Epodes and the Satires, and ahead to the complex combination of public and private found in the Roman Ode. Another Alcaic unit, 2.19-20, marks the inspiration that leads to the sublimity of 3.1-6.

\section{INDEX}

Keywords: Horace, unity, discontinuity, manuscripts, division, commentary, Jani, Watson, Fraenkel, Alcaics, trees, heirs, Roman Ode, iam, vocatives, Meineke's Law 